\title{
A Comparative Study On Self-Healing Methods of Concretes By Sporosarcina Pasteurii Bacteria
}

Mohammad Mirshahmohammad ( $\triangle$ mohammad.mir@znu.ac.ir)

University of Zanjan https://orcid.org/0000-0002-5545-2181

\section{Hamid Rahmani}

University of Zanjan

Mahdi Maleki-Kakelar

University of Zanjan

Abbas Bahari

University of Zanjan

\section{Research Article}

Keywords: Bacterial carbonate precipitation, Self-healing, Calcium salts, Air-entrained concrete

Posted Date: August 24th, 2021

DOl: https://doi.org/10.21203/rs.3.rs-744114/v1

License: (c) (i) This work is licensed under a Creative Commons Attribution 4.0 International License. Read Full License 


\section{Abstract}

Biological methods (adding bacteria to the concrete mixtures) among the most recently investigated procedures increase the durability of concrete and repair concrete cracks. In the present study, different biological methods were used to heal the cracks of concrete and the most suitable method was subsequently introduced. For this purpose, the culture medium and bacterial nutrient inside the concrete mixes and curing solution were separately studied. The effect of air-entrained agent and various sources of calcium salts as the bacterial nutrient on the healing process was also studied. The results showed that the use of bacterial nutrient inside the concrete mixes has an affirmative impact on the mechanical properties and self-healing characteristics of concretes. With the simultaneous use of Sporosarcina pasteurii bacteria and calcium nitrate-urea or calcium chloride-urea as a bacterial nutrient in the concrete mixture, the 28 days compressive strength of concrete increases by $23.4 \%$ and $7.5 \%$, respectively, which is due to calcium carbonate precipitation. The use of bacterial cells, nutrients, and culture in the concrete mixture provided the ability to heal wide cracks where the healing time is significantly reduced. On the other hand, separation of the bacterial culture medium slightly reduced the self-healing performance of concrete.

\section{Introduction}

Various effective factors such as external loads, shrinkage, gradient temperature, and support settlement can create large stresses within concrete members and cause cracks (Mindess et al. 1981). When cracks form in a continuous network inside the concrete, the durability of concrete can be impaired. Usually in this process, the permeability significantly increases, and with the entry of corrosive liquids and gases into the concrete, reinforcements are corroded and therefore the service life of concrete structure is decreased. Without immediate and proper treatment, cracks tend to propagate and eventually require costly repair. Therefore, reducing the permeability of concrete after cracking is widely considered to be the principal step in concrete maintenance. However, repairing the cracks and reducing the porosity of concrete with conventional methods requires a lot of time and costs and sometimes has aspects that are harmful to the environment and health (Xu et al. 2014). Accordingly, achieving a new auto eco-friendly method is of special importance for filling cracks and pores in concrete. It should be noted that some cracks and pores, up to a width of $0.1 \mathrm{~mm}$ in concrete, are closed by hydration of unhydrated cement, which is known as the inherent self-healing of concrete; but this process is not enough to fill wide cracks (Edvardsen et al. 1999). The new method uses a microbial process (using specific bacteria and calcium source) to structurally repair damaged structures, in which a metabolic activity leads to the deposition of calcium carbonate in the form of calcite which repairs wide cracks in a short time and reduces concrete permeability(Chahal et al. 2012).

To date, bacterial calcite precipitation has been frequently applied using ureolytic bacteria in a calciumrich environment. In this method, bacteria produce a urea enzyme, which acts as a biological catalyst in biological reactions that raise the $\mathrm{pH}$ of the medium (Dick et al. 2006). $\mathrm{Ca}^{+2}$ ions in the medium are not likely used by bacteria, rather, they accumulate outside the cell. These bacteria absorb negative charges 
in their cell walls that draw cations such as $\mathrm{Ca}^{+2}$ supplied from a calcium source. The cations then react with the carbonate to produce calcium carbonate precipitations in the cell wall of the bacterium. Reactions are taken by Eqs. (1) and (2) (Siddique et al. 2011):

$$
\begin{aligned}
& \mathrm{Ca}^{2+}+\mathrm{Cell} \rightarrow \mathrm{Cell}-\mathrm{Ca}^{2+}(1) \\
& \mathrm{Cell}-\mathrm{Ca}^{2+}+\mathrm{CO}_{3}^{2-} \rightarrow \mathrm{Cell}-\mathrm{CaCO}_{3} \downarrow
\end{aligned}
$$

Urea hydrolysis by bacterial urease is a prevalent microbial process that is very suitable for biomineralization and biosorption applications(Hammes et al. 2002). Specifically, bacteria have a high surface-to-volume ratio and a completely negative charge potential that facilitates the adsorption of soluble metal ions to their surface (Bachmeier et al. 2002; Beveridge 1988). Based on the above equations, the ureolytic bacteria have two major roles:

\section{Enzyme manufacture because of high urease activity,}

2. manufacturing suitable substrate for the continuous formation and dense of calcium carbonates in the walls of bacterial cells.

Many studies have used mineral-producing bacteria for self-healing concrete, where various bacteria can precipitate calcium carbonate (Van Tittelboom et al. 2010). For instance, Tittelboom et al. used Bacillus Sphaericus to repair cracks in concrete. They indicated that pure bacterial culture could not repair cracks; however, when bacteria in the silica gel were protected against the high alkalinity of the concrete environment, the cracks were completely repaired (Van Tittelboom et al. 2010). Jonkers et al. concluded that alkali-resistant spore-forming bacteria related to the genus Bacillus represent promising candidates for application as a self-healing agent in the concrete and probably other cement-based materials. Evidences showed that cement stone incorporated bacterial spores can convert concomitantly incorporated calcium lactate to calcium carbonate-based minerals upon activation by crack ingress water (Jonkers et al. 2010).

Muynck et al. investigated the precipitation of calcium carbonate layers on the surface of mortar specimens by bacteria to improve the durability of cementitious materials. This surface precipitation of calcium carbonate crystals reduced water absorption, chlorine penetration, and carbonation by about $65-$ $90 \%, 25-30 \%$, and $10-40 \%$, respectively depending on the porosity of the specimens and increased resistance to freezing and thawing (De Muynck et al. 2008).

Tayebani et al. have studied biological self-healing on the durability properties of concretes including water absorption, chloride ion penetration, electrical resistance, and corrosion of steel in concrete. Results of the experiments showed that the use of bacteria, especially Sporosarcina Pasteurii in mixing water or curing water, improves the durability properties of the concretes (Tayebani et al. 2019).

Researches have protected bacteria in concretes using an air-entraining agent, silica gel, and polyurethane (Wang et al. 2012; Stuckrath et al. 2014; Erşan et al. 2015). Also, researchers have studied the effects of different calcium sources in concretes and/or in the curing environment and use of 
bacterial as a surface treatment on the durability, mechanical properties, and self-healing of concretes and mortars. Also, the separation of bacterial culture medium on the electrical resistivity, chloride penetration and mechanical properties of mortars have been separately studied (Xu et al. 2014; Tayebani et al. 2019; Parastegari et al. 2019; Senthilkumar et al. 2015; De Muynck et al. 2008), but the comparative study of these cases on the self-healing process and on the mechanical properties of concretes are not conducted. Therefore, in this research, in order to achieve the most suitable biological method for healing cracks with a width of 200 microns in the shortest possible time, concrete specimens with different mixtures were investigated. The culture medium and bacterial nutrient including calcium nitrate and calcium chloride inside the concrete and in the curing environment have been studied separately. Also, the effect of entrained air on the bacteria covering and cracks healing has been studied. Moreover, mechanical properties of the concretes such as compressive and tensile strengths and secondary tensile strength after self-healing have been investigated.

\section{Materials And Methods}

\section{2-1-Bacteria and growth conditions}

As a urease producing bacterium, Sporosarcina Pasteurii (S. Pasteurii) belonging to the bacillus family was used in this study. This microorganism was prepared as a lyophilized ampoule from the collection center of industrial fungi and bacteria of Iran with the identification number PTCC 1645 (DSM 33).

Bacterial cultivation was carried out in a culture medium containing $20 \mathrm{~g} / \mathrm{l}$ yeast extract, $10 \mathrm{~g} / \mathrm{l} \mathrm{NH_{4 }}$ Cl at a $\mathrm{pH}$ value of 8.5. After autoclaving the broth solution, inoculation of $S$. pasteurii cells was undertaken in $200 \mathrm{ml}$ of a growth medium. The culture was aerobically incubated at $30^{\circ} \mathrm{C}$ for $30 \mathrm{~h}$ in a shaker incubator operated at $160 \mathrm{rpm}$. The bacteria were then activated at a concentration of $0.5 \times 10^{7} \mathrm{cells} / \mathrm{ml}$ under sterile conditions. Centrifuged bacteria were separately used in some mixtures where the bacteria and the culture medium were transferred to the falcons to be placed in the centrifuge at $4000 \mathrm{rpm}$ for 10 minutes. After 10 minutes, the bacteria precipitated at the bottom of the falcons. This step must be repeated several times to ensure that all bacteria are separated from their culture medium. At the end of this step, the deposited bacteria were washed with water and get ready to be transferred to the concrete mixing water.

The activity of urease enzyme was indirectly measured by the amount of urea hydrolysis. Hydrolysis of urea involves the conversion of urea to ammonium and carbonate ions in the presence of water. It was measured according to the electrical conductivity change of bacterial suspension over time at the absence of calcium ions. Accordingly, $1 \mathrm{ml}$ of bacterial suspension was added to $9 \mathrm{ml}$ of $1.11 \mathrm{M}$ urea solution, and the change in electrical conductivity of the solution after 5 minutes was measured (Kakelar et al. 2016). It is worthwhile noting that, $1 \mathrm{mS} / \mathrm{min}$ is correlated with the enzyme activity of $11 \mathrm{mM}$ urea. $\min ^{-1}$ in the measured range of activities

\section{2-2-Concrete materials and control mixture}


The cement used in this study is type II Portland cement of Kurdistan factory. The properties of the cement are shown in Table 1. Crushed coarse and fine aggregates with a nominal maximum size of 19.5 and $5 \mathrm{~mm}$, respectively, were used in the mixtures. Chloride free Flowcem wb44 as an air entrainment agent was used to stabilize air voids in concrete, where it is prepared according to ASTM C260 (ASTM C260-1986). Various dosages of air entrainment agent (AEA) were tested and the amount of air content of fresh mixed concrete was measured according to ASTM C231 (ASTM C231-2010). The results showed that the addition of $0.3 \%$ AEA by weight of cement creates $5 \%$ air voids in concrete.

Table 1. Physical, mechanical and chemical properties of the cement

\begin{tabular}{|llll|}
\hline Amount (\%) & Chemical composition & Amount & Physical properties \\
\hline 21.5 & $\mathrm{SiO}_{2}$ & 3250 & Blaine $\left(\mathrm{cm}^{2} / \mathrm{gr}\right)$ \\
\hline 4.69 & $\mathrm{Al}_{2} \mathrm{O}_{3}$ & 140 & Initial setting time (min) \\
\hline 4.32 & $\mathrm{Fe}_{2} \mathrm{O}_{3}$ & 180 & Final setting time (min) \\
\hline 64 & $\mathrm{CaO}$ & Amount & Mechanical properties \\
\hline 1.45 & $\mathrm{MgO}$ & 23.5 & $3 \mathrm{~d}(\mathrm{MPa})$ Compressive strength \\
\hline 0.56 & $\mathrm{~K}_{2} \mathrm{O}$ & 32.0 & $7 \mathrm{~d}(\mathrm{MPa})$ Compressive strength \\
\hline 2.34 & $\mathrm{SO}_{3}$ & 51.0 & $28 \mathrm{~d}(\mathrm{MPa})$ Compressive strength \\
\hline
\end{tabular}

The control concrete mixture as reference mixture was designed according to ACl-211.1 (ACl 211.1-1991) for 28 days compressive strength of $30 \mathrm{MPa}$ and slump of $75-100 \mathrm{~mm}$. The mixing proportions are given in Table 2.

Table 2. Control mixture for $1 \mathrm{~m}^{3}$ of concrete.

\begin{tabular}{llll} 
Fine aggregate & Coarse aggregate & Water & Portland cement \\
\hline $846\left(\mathrm{~kg} / \mathrm{m}^{3}\right)$ & $822\left(\mathrm{~kg} / \mathrm{m}^{3}\right)$ & $186\left(\mathrm{~kg} / \mathrm{m}^{3}\right)$ & $400\left(\mathrm{~kg} / \mathrm{m}^{3}\right)$
\end{tabular}

\section{2-3- Concrete mixtures}

In this study, 7 concrete mixtures were developed to investigate different methods of healing process using S. pasteurii according to Table 3. The bacteria were slowly added to the concrete at the end of the mixing process. Also, in case of calcium chloride-urea or calcium nitrate-urea incorporation in concrete mix design as bacteria nutrition, they were mixed with half of the concrete mixing water and gradually added to the mixer. AEA was added to the six groups of mixtures during concrete construction (Table 3). Fresh concretes were then poured and compacted in two or three layers depending on the size of specimens. Then, the specimens were demolded after $24 \mathrm{~h}$ of moist curing and the samples were divided 
into three groups according to their curing environment (see Table 3). Specimens containing calcium chloride-urea and calcium nitrate-urea were cured in water, but other specimens were cured in water containing calcium chloride-urea or calcium nitrate-urea. In Table 3, M, S, H, Ni-2, and Cl-2 indicate control concrete, concrete containing centrifuged bacteria, concrete containing $5 \%$ air content, concrete containing bacteria and calcium nitrate-urea, and concrete containing bacteria and calcium chloride-urea, respectively. Also, $\mathrm{Ni}-1$ and $\mathrm{Cl}-1$ refer to the concretes containing bacteria in which they were cured in water containing calcium nitrate-urea and calcium chloride-urea, respectively. Moreover, Table 4 shows the amount of urea and bacteria nutrient used in bacterial concrete and/or in curing solutions per 1 lit of fresh concrete or curing water.

Table 3. Concrete mix designs and their curing environment.

\begin{tabular}{|c|c|c|c|}
\hline $\begin{array}{l}\text { Specimen's } \\
\text { code }\end{array}$ & Bacterial ingredients & curing environment & $\begin{array}{l}\text { Air content } \\
(\%)\end{array}$ \\
\hline M & - & water & 0 \\
\hline $\mathrm{Cl}-1$ & Bacteria + culture media & $\begin{array}{l}\text { Water containing calcium } \\
\text { chloride-urea }\end{array}$ & 0 \\
\hline $\mathrm{Ni}-1$ & Bacteria + culture media & $\begin{array}{l}\text { Water containing calcium } \\
\text { nitrate -urea }\end{array}$ & 0 \\
\hline $\mathrm{Cl}-2$ & $\begin{array}{l}\text { Bacteria + culture media + calcium } \\
\text { chloride-urea }\end{array}$ & water & 0 \\
\hline $\mathrm{Ni}-2$ & $\begin{array}{l}\text { Bacteria + culture media + calcium } \\
\text { nitrate -urea }\end{array}$ & water & 0 \\
\hline $\mathrm{HCl}-1$ & Bacteria + culture media & $\begin{array}{l}\text { Water containing calcium } \\
\text { chloride-urea }\end{array}$ & 5 \\
\hline $\mathrm{HNi}-1$ & Bacteria + culture media & $\begin{array}{l}\text { Water containing calcium } \\
\text { nitrate -urea }\end{array}$ & 5 \\
\hline $\mathrm{HCl}-2$ & $\begin{array}{l}\text { Bacteria + culture media + calcium } \\
\text { chloride-urea }\end{array}$ & water & 5 \\
\hline $\mathrm{HNi}-2$ & $\begin{array}{l}\text { Bacteria + culture media + calcium } \\
\text { nitrate -urea }\end{array}$ & water & 5 \\
\hline SHCl-2 & Bacteria + calcium chloride-urea & water & 5 \\
\hline SHNi-2 & Bacteria + calcium nitrate -urea & water & 5 \\
\hline
\end{tabular}

Table 4. Amount of nutrients used in the concrete or curing solutions 


\section{Bacterial nutrient in concrete}

Urea (industrial grade)

Calcium nitrate

(industrial)

Calcium chloride

(industrial)

Per liter of

water

$20 \mathrm{~g} / \mathrm{lit}$

$10 \mathrm{~g} / \mathrm{lit}$

$10 \mathrm{~g} / \mathrm{lit}$

\section{2-4-Experiments}

Compressive strength: According to BS 1881-116 standard, $10 \times 10 \times 10 \mathrm{~cm}$ specimens were tested in the saturated surface dry (SSD) condition after 7 and 28 days of curing. For each design, 3 cubic specimens were made and their average strength was reported (BS 1881-116).

Tensile strength test: According to ASTM C496-90 (ASTM C496-90-2011), this method is used to measure the tensile strength of concretes. Cylindrical samples with dimensions of $10 \times 20 \mathrm{~cm}$ were considered for this purpose. Because some loads during construction are often applied to the concrete members after 7 days of concrete construction and consequently cracks appeared in this time, the age of the specimens was considered to be 7 days.

Secondary tensile strength test (STS): Since the age of cracking of concrete members is often less than 7 days, in this experiment, cracks with a width of 200 microns on cylindrical specimens with a diameter of $100 \mathrm{~mm}$ and a height of $200 \mathrm{~mm}$ was created using splitting tensile strength setup after 7 days of water curing and obtaining the tensile strength. The cracked specimens were then fastened with metal brackets and again were re-cured in the considered curing environment (Table 3). Finally, after 30 days of re-curing, the secondary tensile strength of the specimens was determined. It should be noted that the diameter of each specimen was measured by a digital caliper before and after creating the crack, then, the diameter of the specimen was adjusted by fastening the brackets so that the width of the crack reached 200 microns. Fig. 1 shows how the crack width was measured.

Water passing through cracked specimens: In this test, which is schematically shown in Fig. 2, water flow through the cracks in cylindrical samples with dimensions of $10 \times 20 \mathrm{~cm}$ was measured over time, when self-healing process to be progressed. Similar method to STS test was used to create the crack and keep the crack width constant. To prevent water leakage from the crack at the height of the sample, the crack is sealed with sealant. In this study, water flow was measured after $0,1,2,4,6,8,12,16,18,20,22,24,26$, 28 , and 30 days of re-curing for 6 hours, and the average of 3 specimens were reported (Rahmani et al. 2015). 0-day re-curing indicates no re-curing and measures the amount of water passing at the moment of cracking as a basis for the self-healing assessment.

\section{Results And Discussions}

\section{3-1-Visual observations of self-healing}


To investigate the effect of self-healing and the extent to which the cracks are filled with bacterial precipitation, the cracked specimens were taken out of the tank at different ages and the healing of the cracks was determined. The mixtures in which the bacterial nutrient was added into the curing environment had a slower rate of self-healing. The rate of self-healing increased dramatically in $\mathrm{Ni}-2$ and $\mathrm{Cl}-2$ mixtures in the first 10 days of re-curing.

\section{3-2-Compressive strength test}

The compressive strength results of the mixture and the percentage of increase or decrease in the compressive strength compared to the control concrete are shown in Fig. 3. It is clear that how to use of bacteria and its nutrient play an important role in increasing or decreasing the compressive strength of concretes. When calcium nitrate-urea and calcium chloride-urea were added to Ni-2 and $\mathrm{Cl}-2$ mixtures; compressive strength respectively increased by $22.22 \%$ and $9.54 \%$ after 7 days of curing and $23.43 \%$ and $7.5 \%$ after 28 days of curing compared to the control concrete at the same ages. Because the source of calcium is available to bacteria, the ability of bacteria to precipitate calcium carbonate is present from the beginning, which increases the compressive strength. This process was also seen in the concretes containing air content. However, other mixtures showed a decrease in the compressive strength compared to the control concrete. Although, the air content in the concrete itself reduces the compressive strength, but when bacteria and bacterial nutrient were used in the concretes containing $5 \%$ air voids, this reduction in strength is partially compensated. $\mathrm{HNi}-2$ had a $7.5 \%$ increase in the compressive strength after 7 days of curing compared to the control concrete. Obviously, if the bacterial nutrient is used in curing environment, calcium carbonate precipitation is very slow, but it is expected that the performance of this type of curing will be evident in the self-healing process. Moreover, the performance of calcium nitrate in all mixtures was better than that of calcium chloride. Fig. 4 shows the relative increase in the compressive strength of the mixtures containing bacteria nutrient in comparison with the concretes that the bacteria nutrients were added to the curing water after 7 days and 28 days curing. In comparison to the control concrete, the increase in the compressive strength of $\mathrm{Ni}-2$ and $\mathrm{Cl}-2$ mixtures after 7 days of curing was more than 28 days of curing. However, a decrease in the compressive strength was observed for other mixtures in comparison to the control one at the age of 7 days in comparison with 28 days. In fact, it can be inferred that the activity of bacteria is higher at the younger ages.

The effect of adding and separating culture medium on the compressive strength of the relevant bacterial mixtures after 7 days and 28 days curing is shown in Fig. 5. According to Fig. 5, it can be pointed out that centrifugation of bacteria significantly reduces the compressive strength and it is better to use the bacteria with the culture medium in concretes.

\section{3-2-Tensile strength test}

Tensile strength test results of the concretes are shown in Fig. 6-a. As shown, all mixtures even concrete containing air-entrained agent, have higher tensile strength than control concrete, which can be due to the calcium carbonate precipitation. Therefore, it can be concluded that entrained airs in bacterial concrete can increase tensile strength despite reduction in the compressive strength. According to Fig. 6-b which 
shows the relative increase in tensile strength compared to control concrete, the highest tensile strength was related to $\mathrm{Ni}-2$ mixture with $20.56 \%$ increase in tensile strength. Also, similar discussions to compressive strength can be drawn for the tensile strength variations.

\section{3-4-Secondary tensile strength (STS) test}

The results of STS test after 5 weeks of re-curing and the ratio of secondary tensile strength to the relevant initial tensile strength are shown in Fig. 7-a. All mixtures be able to achieve relatively higher tensile strength than the control concrete, which indicates a mechanical improvement in cracked concretes, although they have not achieved their initial tensile strength. However, $\mathrm{Cl}-2, \mathrm{HCl}-2$, and $\mathrm{Ni}-2$ mixtures gained the maximum secondary tensile strength, respectively where the bacterial nutrients were added to the mixtures. Fig. 7-b shows the relative increase in STS compared to the control concrete. The highest STS was related to $\mathrm{Ni}-2$ and $\mathrm{Cl}-2$ mixtures, which were associated with $109 \%$ and $104 \%$ increase in tensile strength compared to the control concrete, respectively, which is caused by the precipitation of calcium carbonate and the repair of cracks by bacteria. Since the cracks of the specimens were closed after two weeks of curing according to the water passing through the crack test, so further re-curing has made the structure of the repaired crack more compacted and the tensile strength has been significantly improved. This phenomenon has been delayed in other mixtures and has slowly increased the tensile strength. Also, $\mathrm{HCl}-2, \mathrm{HNi}-2, \mathrm{SHCl}-2$, and $\mathrm{SHNi}-2$ mixtures with $5 \%$ air voids had higher secondary tensile strength than $\mathrm{HCl}-1$ and $\mathrm{HNi}-1$ mixtures. Fig. 8-a shows how the mixture $\mathrm{Ni}-2$ repaired the crack after 5 weeks of re-curing. On the other hands, its secondary failure under splitting test is presented in Fig. $8 \mathrm{~b}$, which indicates the failure of the specimen exactly occurred from the healed crack.

\section{3-5-Water passing through the cracked specimens}

Water passing through the cracked specimens was measured after $0,1,2,4,6,8,12,16,18,20,22,24,26$, 28 , and 30 days of re-curing under the mentioned curing environments. All mixtures except the control mixture completely filled the cracks during 30 days of re-curing. In this section, mixtures were divided into two groups.

The first group includes the mixtures $\mathrm{M}, \mathrm{Cl}-1, \mathrm{Ni}-1, \mathrm{HCl}-1$, and $\mathrm{HNi}-1$ where bacterial nutrient was added into the curing solution except the control mixture $(\mathrm{M})$. This group had a slower rate of self-healing than other specimens, and the control mixture had the worst performance. The results of the first group are shown in Fig. 9-a where the amount of water passing through the crack in entrained air specimens was significantly reduced after 12 days of re-curing, and then was completely repaired after 20 days of recuring. However, mixtures without entrained air were completely repaired after 30 days of re-curing. There was no significant difference between the effect of calcium nitrate and calcium chloride as a bacterial nutrient in the self-healing process, but generally, calcium nitrate appeared better. Since bacteria have more space in the entrained concretes, they can survive longer in the concretes and therefore their performance in the self-healing process will be better. It should be noted that when water does not penetrate during 6 hours through the repaired crack, it is assumed that the crack was completely repaired, but in fact, the crack was not perfectly repaired according to STS test results. 
The second group includes $\mathrm{Cl}-2, \mathrm{Ni}-2, \mathrm{HCl}-2, \mathrm{HNi}-2, \mathrm{SHCl}-2$, and $\mathrm{SHNi}-2$ mixtures, where bacterial nutrient has been used in the concrete mixtures. The impact of nitrate calcium-urea on the self-healing process is more significant in comparison to the first group. According to Fig. 9-b, the cracks were completely repaired up to 14 days of re-curing and $\mathrm{Ni}-2$ showed the best performance in which the crack was completely healed after 8 days of re-curing. Also, $\mathrm{HCl}-2$, $\mathrm{HNi}-2, \mathrm{SHCl}-2$, and $\mathrm{SHNi}-2$ mixtures did not differ much in terms of self-healing, however, when centrifuged bacteria and air-entraining agent were used, the self-healing process was slowly delayed.

\section{Self-healing Agent Assessment}

\section{4-1-Fourier transform infrared spectroscopy (FTIR)}

This method is used as a powerful and developed method for determining the structure and measurement of chemical species. Also, this method is mainly used to identify organic compounds because the spectra of these compounds are usually complex and have a large number of maximum and minimum peaks that can be used for comparative purposes (Hajjia et al. 2015). In this study, the selfhealing agent from the healed surface of the mixture that had the best performance in the self-healing process (Ni-2) was collected and tested. According to Fig. 10, the two absorption peaks at 875 and 712 $\mathrm{cm}^{-1}$ obtained from FTIR spectrum of the restorative agent confirms that the self-healing agent is calcite (Shan 2007). On the other hand, the relatively weak intensities and the lack of an absorption peak at 1420 $\mathrm{cm}^{-1}$ proposes that calcite is a minor phase, or highly hydrated as would be other form of $\mathrm{CaCO}_{3}$ crystals (Harrington 1927).

\section{4-2-SEM and XRD analys}

X-ray Diffraction (XRD, D8-Advance, Bruker and scanning from 10 to 80 2theta) and Scanning Electron Microscope (SEM, Leo 440i) were used to analyze the crystal structure of the precipitation.

Concrete specimens were completely dried at room temperature and the samples were collected from the healed surface of the 7 days cured specimens. The results of XRD are shown in Fig.11. X-ray analysis of the self-healing agent was performed for the powders of $\mathrm{Ni}-2$ and $\mathrm{M}$ mixture. Results of XRD were compared with the reference cards of calcium carbonate for $\mathrm{Ni}-2$ that confirm the presence of calcium carbonate as the main product of the reaction mechanism induced by bacterial activity [30]. Also, $\mathrm{Ca}(\mathrm{OH})_{2}, \mathrm{C}-\mathrm{S}-\mathrm{H}$, Ettringite and, Bannisterite were observed in the self-healing agent of the control mixture. It is noteworthy that Bannisterite is a rarely occurring mineral from the mineral class of silicates and germanates. It was probably emanated from the aggregates that may be detached during the self-healing agent collection.

The results of SEM test for $\mathrm{M}, \mathrm{Ni}-2$, and $\mathrm{Cl}-2$ are shown in Figs. 12, 13, and 14, respectively with 2 different magnifications (10 and $20 \mu \mathrm{m}$ ). The potential of calcium carbonate formation in each concrete sample was clearly observed in the concretes containing bacteria. Precipitations with an approximate size of 5-15 $\mu \mathrm{m}$ in cubic and spherical shapes such as calcite and vaterite were observed. Also, ettringite, calcium 
hydroxide (portlandite), and C-S-H crystals are visible in the SEM observation of the mixtures. However, it is evident that portlandite crystals was consumed by bacteria and little portlandite can be found in the bacteria concrete. Consequently, C-S-H gel and ettringite crystal were simply found in the bacterial concrete (Fig. 13).

\section{Conclusion}

In this study, self-healing process of different methods of using S. pasteurii with a concentration of $0.5 \times 107 \mathrm{cell} / \mathrm{ml}$ in plain and $5 \%$ entrained air concretes including calcium chloride-urea or calcium nitrateurea as a bacterial nutrient in the concrete mixtures or in the curing environments was investigated. Separation of bacterial culture medium was also investigated in two separate mixtures. Compressive and tensile strength of non-cracked specimens were measured and then cracked specimens were re-cured for 30 days. Then, the self-healing process including water passing through the healed crack at different ages of re-curing, and the secondary tensile strength after re-curing were measured. Also, microstructural assessment was considered to find out more details about the self-healing process. Based on the results and discussions, the following results were obtained:

- How to use bacterial nutrients in the concretes has a great impact on the mechanical and the selfhealing properties of the concretes.

- With the simultaneous use of sporosarcina pasteurii and calcium nitrate-urea or calcium chlorideurea as a bacterial nutrient in the concrete mixture, the 28 days compressive strength of concrete increases by $23.43 \%$ and $7.5 \%$, respectively, which is due to calcium carbonate precipitation.

- The use of bacteria and its nutrient in the ordinary concrete mixtures and concretes containing $5 \%$ entrained air voids increases the tensile strength up to $20.5 \%$. Apparently, the effect of calcium carbonate precipitation on the increasing tensile strength is far greater than compressive strength.

- The use of sporosarcina pasteurii in the concrete mixture along with providing bacterial nutrients provides the ability to repair wide cracks in a short time where their initial tensile strength can be recovered.

- The use of bacteria with the culture medium has a greater effect on the acquisition of compressive strength and secondary tensile strength than the separation of the bacterial culture medium.

- Air bubbles reduce the compressive strength of concrete themselves, but 7 days compressive strength of $\mathrm{HNi}-2$ mixture showed $7.5 \%$ increase in compressive strength in comparison with the control concrete. Also, bacterial concretes containing $5 \%$ air voids had an acceptable performance in the self-healing process

- According to microstructural studies, the white agent that led to the repair of cracks was calcium carbonate, and in fact, bacterial concrete can produce calcium carbonate to repair cracks.

\section{Declarations}

Ethics approval and consent to participate: Not applicable 
Funding: Not applicable

Consent for publication: Not applicable

Availability of data and materials: Available

Competing interests: The authors declare that they have no competing interests

Authors' contributions: All authors contributed to the study conception and design. Material preparation, data collection and analysis were performed by [Mohammad Mirshahmohammad], [Hamid Rahmani], [Mahdi Maleki-Kakelar] and [Abbas Bahari]. The first draft of the manuscript was written by [Mohammad Mirshahmohammad] and all authors commented on previous versions of the manuscript. All authors read and approved the final manuscript.

Acknowledgments: Acknowledgments of the Supervisors, Department of Civil Engineering and Modern Biological Research Institute of Zanjan University.

\section{References}

1. ASTM C (2011) Standard test method for splitting tensile strength of cylindrical concrete specimens. C496/C496M-11

2. ASTM C (1986) 260. Standard Specification for Air-Entraining Admixtures for Concrete

3. ASTM C (2010) Standard test method for air content of freshly mixed concrete by the pressure method. C231 / C231 M-10

4. Bachmeier KL, Williams AE, Warmington JR, Bang SS (2002) Urease activity in microbiologicallyinduced calcite precipitation. J Biotechnol 93(2):171-181. https://doi:10.1016/s01681656(01)00393-5

5. Beveridge TJ (1988) The bacterial surface: general considerations towards design and function. Can J Microbiol 34(4):363-372. https://doi.org/10.1139/m88-067

6. Chahal N, Siddique R, Rajor A (2012) Influence of bacteria on the compressive strength, water absorption and rapid chloride permeability of fly ash concrete. Constr Build Mater 28(1):351-356. https://doi:10.1016/j.conbuildmat.2011.07.042

7. De Muynck W, Cox K, De Belie N, Verstraete W (2008) Bacterial carbonate precipitation as an alternative surface treatment for concrete. Constr Build Mater 22(5):875-885. https://doi.org/10.1016/j.conbuildmat.2006.12.011

8. De Muynck W, Debrouwer D, De Belie N, Verstraete W (2008) Bacterial carbonate precipitation improves the durability of cementitious materials. Cement concrete Research 38(7):1005-1014. https://doi.org/10.1016/j.cemconres.2008.03.005

9. Dick J, De Windt W, De Graef B, Saveyn H, Van der Meeren P, De Belie N, Verstraete W (2006) Biodeposition of a calcium carbonate layer on degraded limestone by Bacillus species. Biodegradation 
17(4):357-367. https://doi.org/10.1007/s10532-005-9006-x

10. Dixon DE, Prestrera JR, Burg GR, Chairman SA, Abdun-Nur EA, Barton SG, Lee SH (1991) Standard Practice for Selecting Proportions for Normal, Heavyweight, and Mass Concrete (ACI 211.1-91)

11. Edvardsen C (1999) Water permeability and autogenous healing of cracks in concrete. In Innovation in concrete structures: Design and construction (pp. 473-487). Thomas Telford Publishing. https://doi/pdf/10.1680/iicsdac.28241.0047

12. Erşan Y, Da Silva FB, Boon N, Verstraete W, De Belie N (2015) Screening of bacteria and concrete compatible protection materials. Constr Build Mater 88:196-203. https://doi.org/10.1016/j.conbuildmat.2015.04.027

13. Hajjia S, Turkia T, Boubakric A, Amora MB, Mzoughid N (2015) Study of cadmium adsorption onto calcite using full factorial experiment design. In Presented at the 5th Maghreb Conference on Desalination and Water Treatment-CMTDE (Vol. 2015). https://doi:10.5004/dwt.2017.21079

14. Hammes F, Verstraete W (2002) Key roles of pH and calcium metabolism in microbial carbonate precipitation. Reviews in environmental science biotechnology 1(1):3-7. https://doi.org/10.1023/A:1015135629155

15. Harrington EA (1927) X-ray diffraction measurements on some of the pure compounds concerned in the study of Portland cement. American journal of science 5(78):467-479. https://doi.org/10.2475/ajs.s5-13.78.467

16. Jonkers HM, Thijssen A, Muyzer G, Copuroglu O, Schlangen E (2010) Application of bacteria as selfhealing agent for the development of sustainable concrete. Ecological engineering 36(2):230-235. https://doi.org/10.1016/j.ecoleng.2008.12.036

17. Kakelar MM, Ebrahimi S (2016) Up-scaling application of microbial carbonate precipitation: optimization of urease production using response surface methodology and injection modification. International journal of environmental science technology 13(11):2619-2628. https://doi.org/10.1007/s13762-016-1070-8

18. Mindess S, Young JF, Darwin D (1981) Concrete Prentice-Hall. Englewood Cliffs, NJ, 481

19. Parastegari N, Mostofinejad D, Poursina D (2019) Use of bacteria to improve electrical resistivity and chloride penetration of air-entrained concrete. Constr Build Mater 210:588-595. https://doi.org/10.1016/j.conbuildmat.2019.03.150

20. Rahmani H, Bazrgar H (2015) Effect of coarse cement particles on the self-healing of dense concretes. Magazine of Concrete Research 67(9):476-486. https://doi.org/10.1680/macr.14.00158

21. Senthilkumar V, Palanisamy T, Vijayakumar VN (2015) Strength characteristics of microbial cement mortars treated in different calcium sources. Advances in Cement Research 27(5):289-296. https://doi.org/10.1680/adcr.14.00002

22. Shan D, Wang S, Xue H, Cosnier S (2007) Direct electrochemistry and electrocatalysis of hemoglobin entrapped in composite matrix based on chitosan and $\mathrm{CaCO} 3$ nanoparticles. Electrochem Commun 9(4):529-534. https://doi.org/10.1016/j.elecom.2006.10.032 
23. Siddique R, Chahal NK (2011) Effect of ureolytic bacteria on concrete properties. Constr Build Mater 25(10):3791-3801. https://doi:10.1016/j.conbuildmat.2011.04.010

24. Simpson LJ (1998) Electrochemically generated CaCO3 deposits on iron studied with FTIR and Raman spectroscopy. Electrochim Acta 43(16-17):2543-2547. https://doi.org/10.1016/S00134686(97)10167-0

25. Standard B (1881) Part-116 (1983) Method for Determination of Compressive Strength of Concrete Cubes. British Standard Institution, London

26. Stuckrath C, Serpell R, Valenzuela LM, Lopez M (2014) Quantification of chemical and biological calcium carbonate precipitation: performance of self-healing in reinforced mortar containing chemical admixtures. Cem Concr Compos 50:10-15. https://doi.org/10.1016/j.cemconcomp.2014.02.005

27. Tayebani B, Mostofinejad D (2019) Self-healing bacterial mortar with improved chloride permeability and electrical resistance. Constr Build Mater 208:75-86.

https://doi.org/10.1016/j.conbuildmat.2019.02.172

28. Van Tittelboom K, De Belie N, De Muynck W, Verstraete W (2010) Use of bacteria to repair cracks in concrete. Cem Concr Res 40(1):157-166. https://doi.org/10.1016/j.cemconres.2009.08.025

29. Wang J, Van Tittelboom K, De Belie N, Verstraete W (2012) Use of silica gel or polyurethane immobilized bacteria for self-healing concrete. Construction building materials 26(1):532-540. https://doi.org/10.1016/j.conbuildmat.2011.06.054

30. Xu J, Yao W (2014) Multiscale mechanical quantification of self-healing concrete incorporating nonureolytic bacteria-based healing agent. Cem Concr Res 64:1-10. https://doi:10.1016/j.cemconres.2014.06.003

\section{Figures}




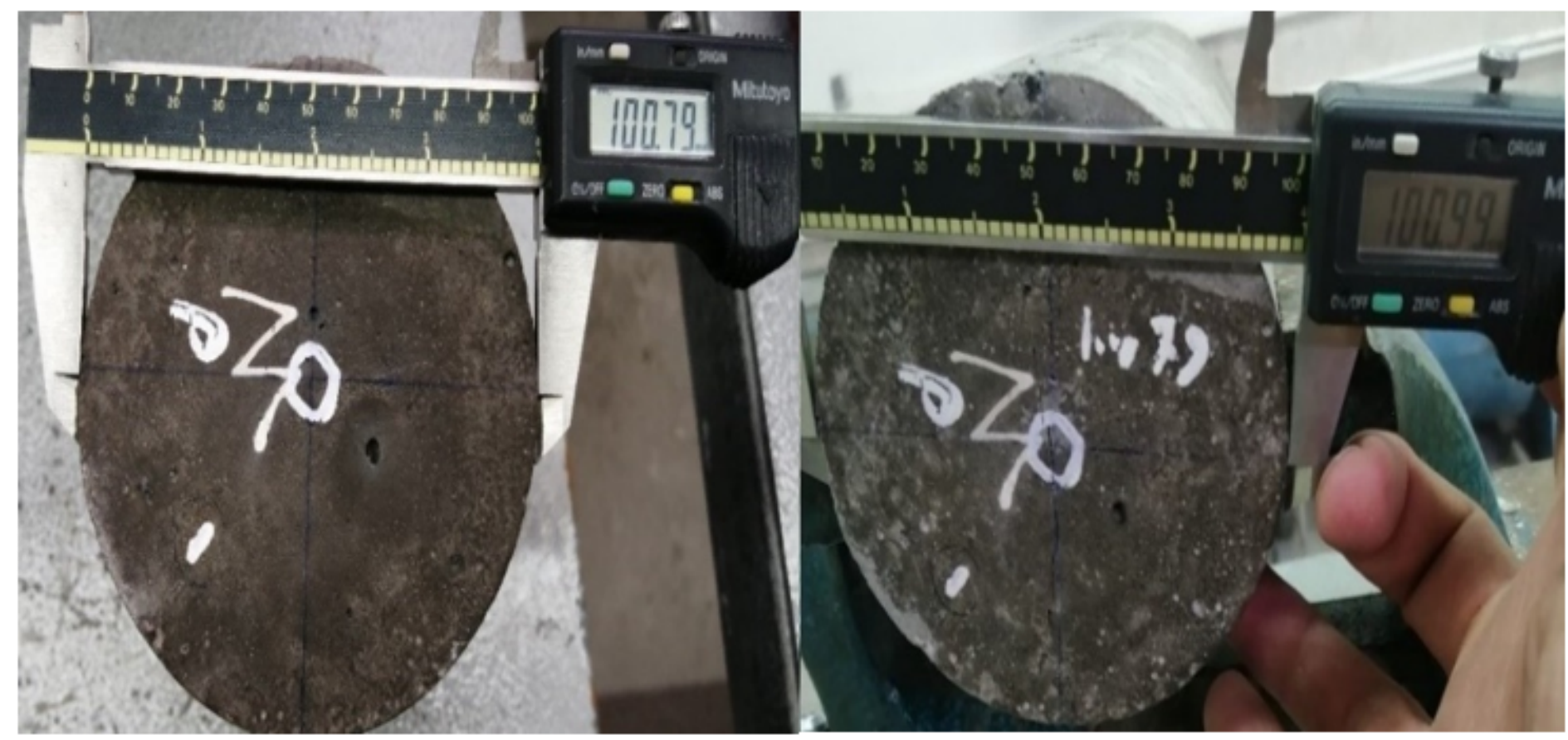

(a)

(b)

\section{Figure 1}

Diameter of the specimen measuring to adjust the crack width: (a) before crack; (b) after crack.

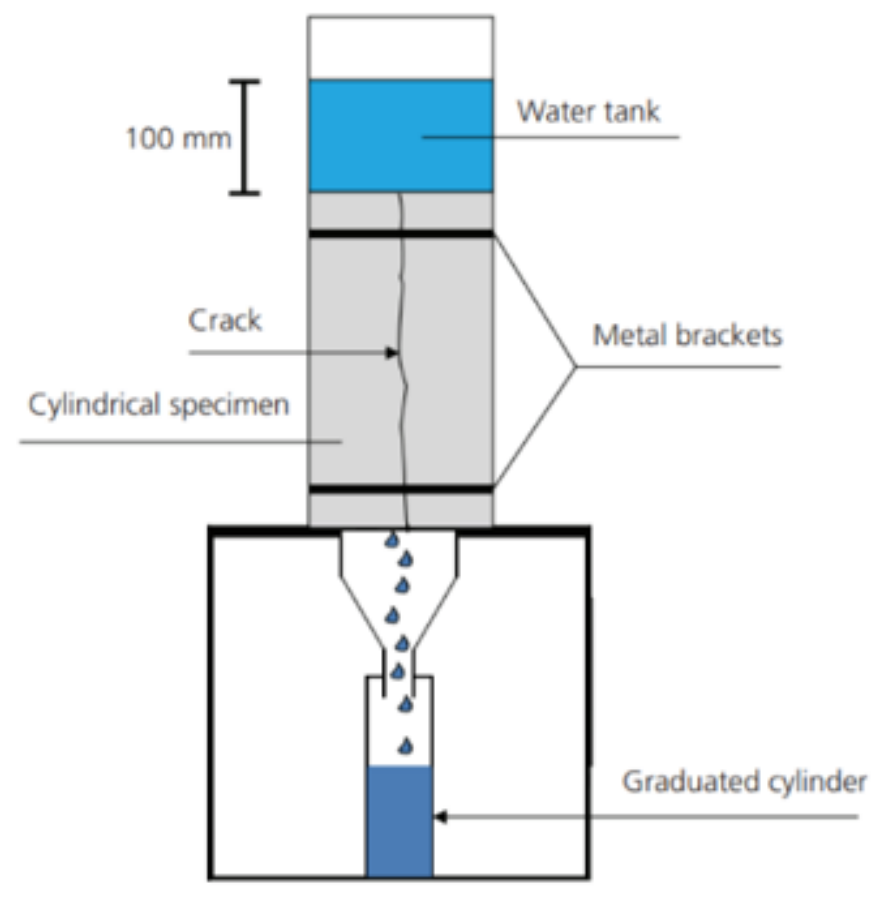

\section{Figure 2}

Schematic illustration of test for water passing through cracked specimen (Rahmani et al. 2015). 


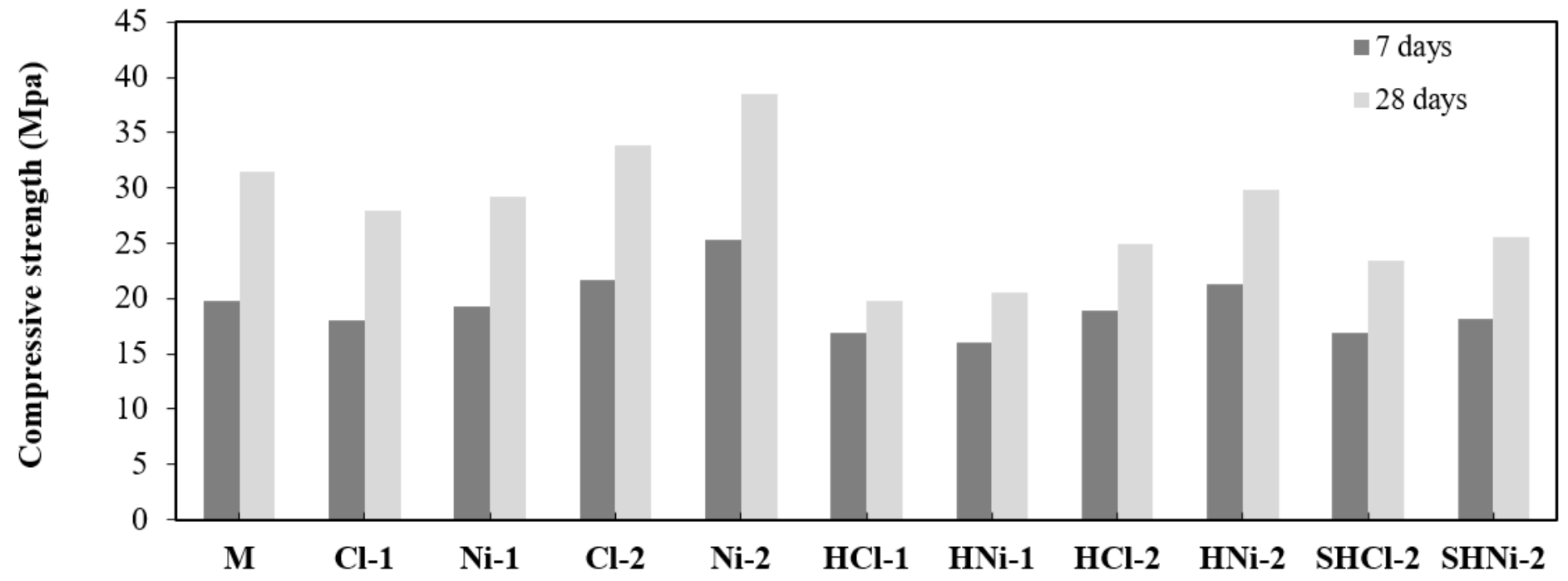

(a)

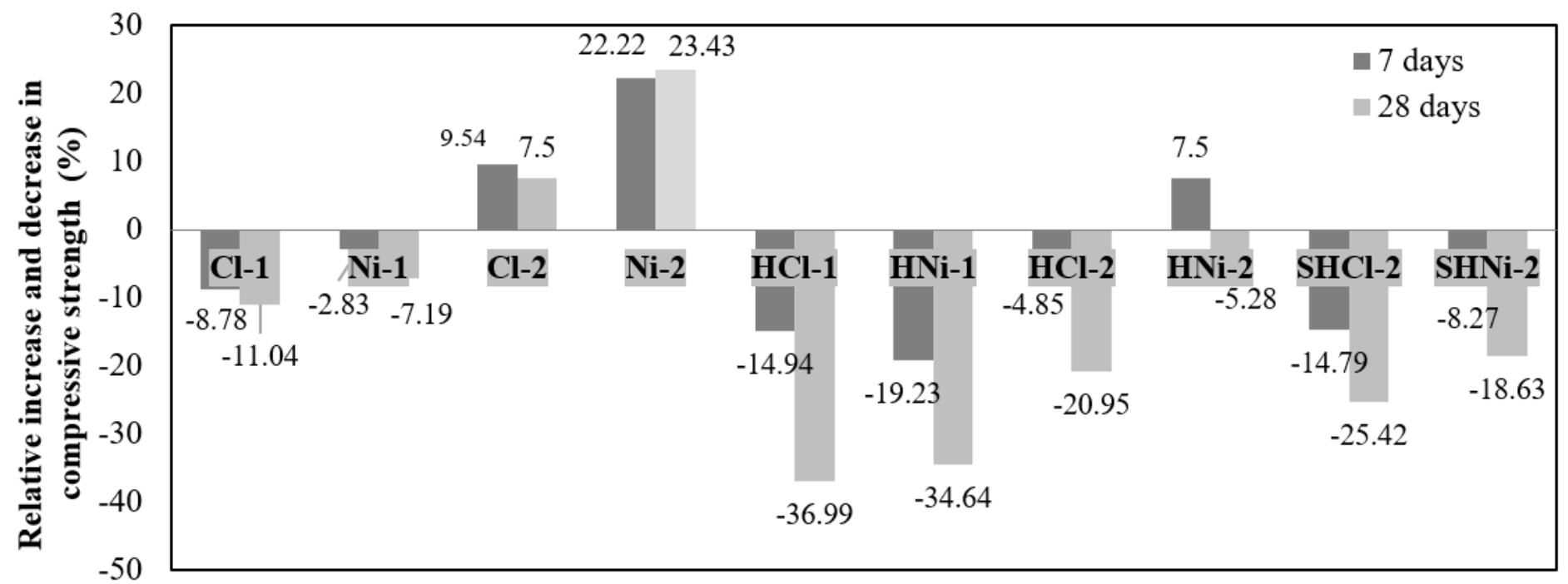

(b)

Figure 3

(a) Compressive strength of mixtures; (b) Relative increase and decrease in compressive strength compared to the control concrete. 


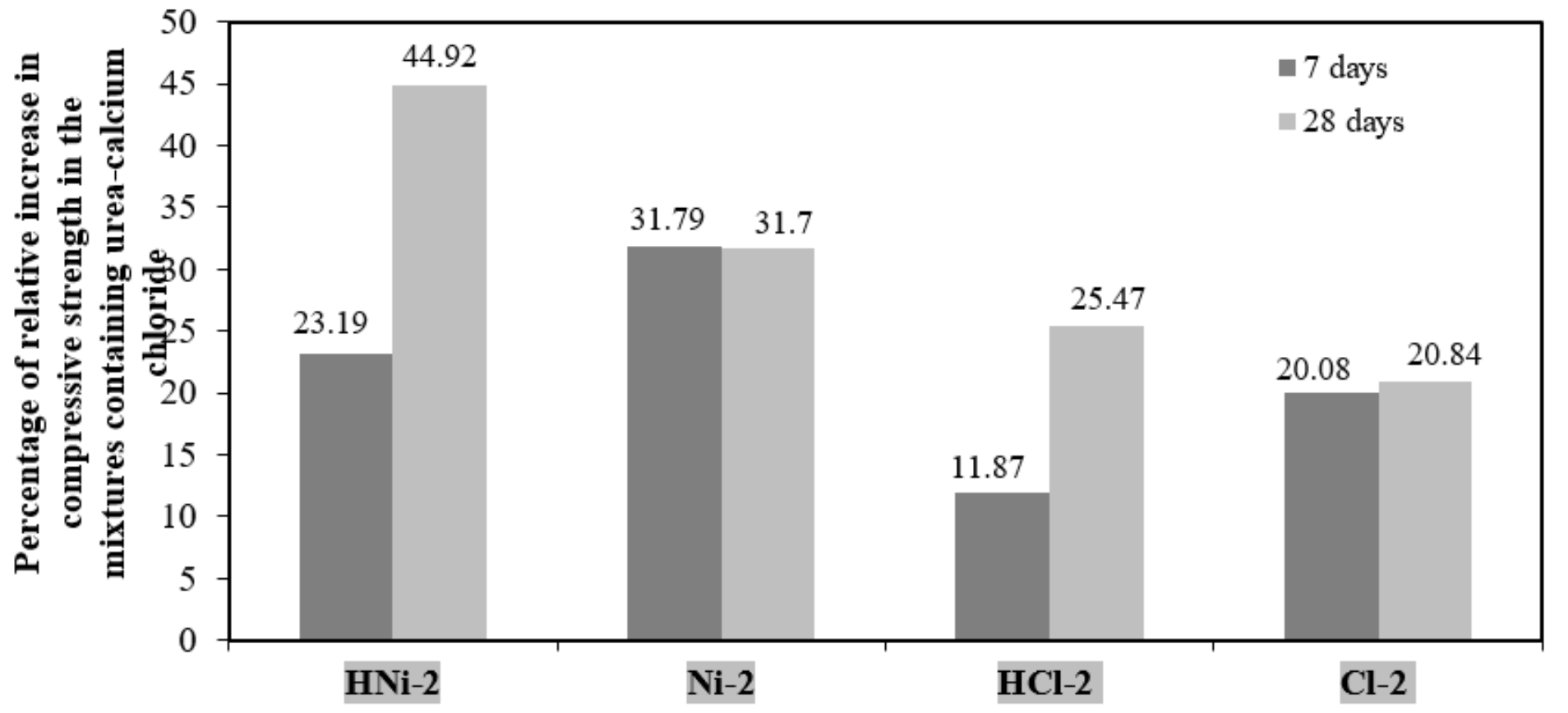

Figure 4

Relative increase in compressive strength in case of adding bacterial nutrient in the mixture of concrete in comparison with adding them to curing solution.

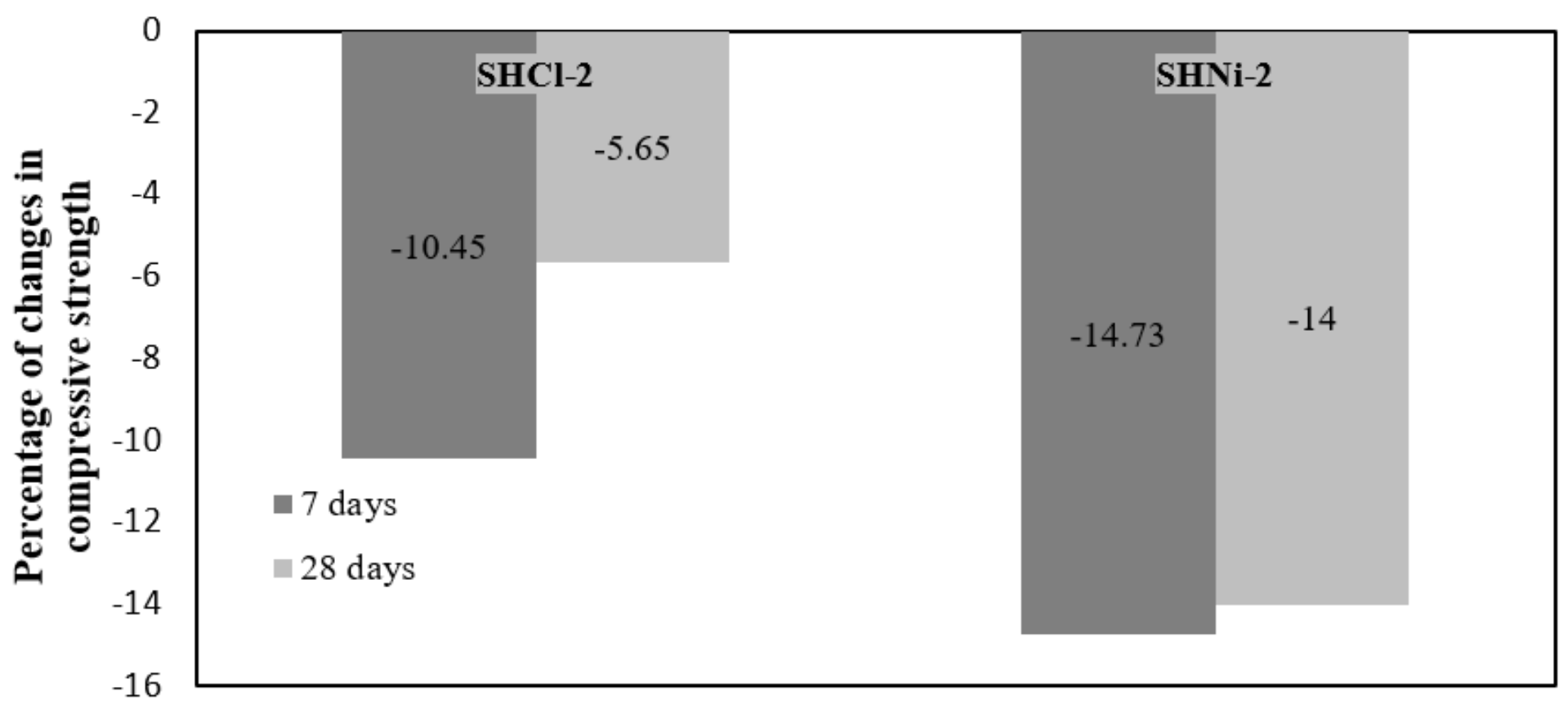

Figure 5

The effect of bacterial culture medium separation on the compressive strength of the relevant mixtures. 


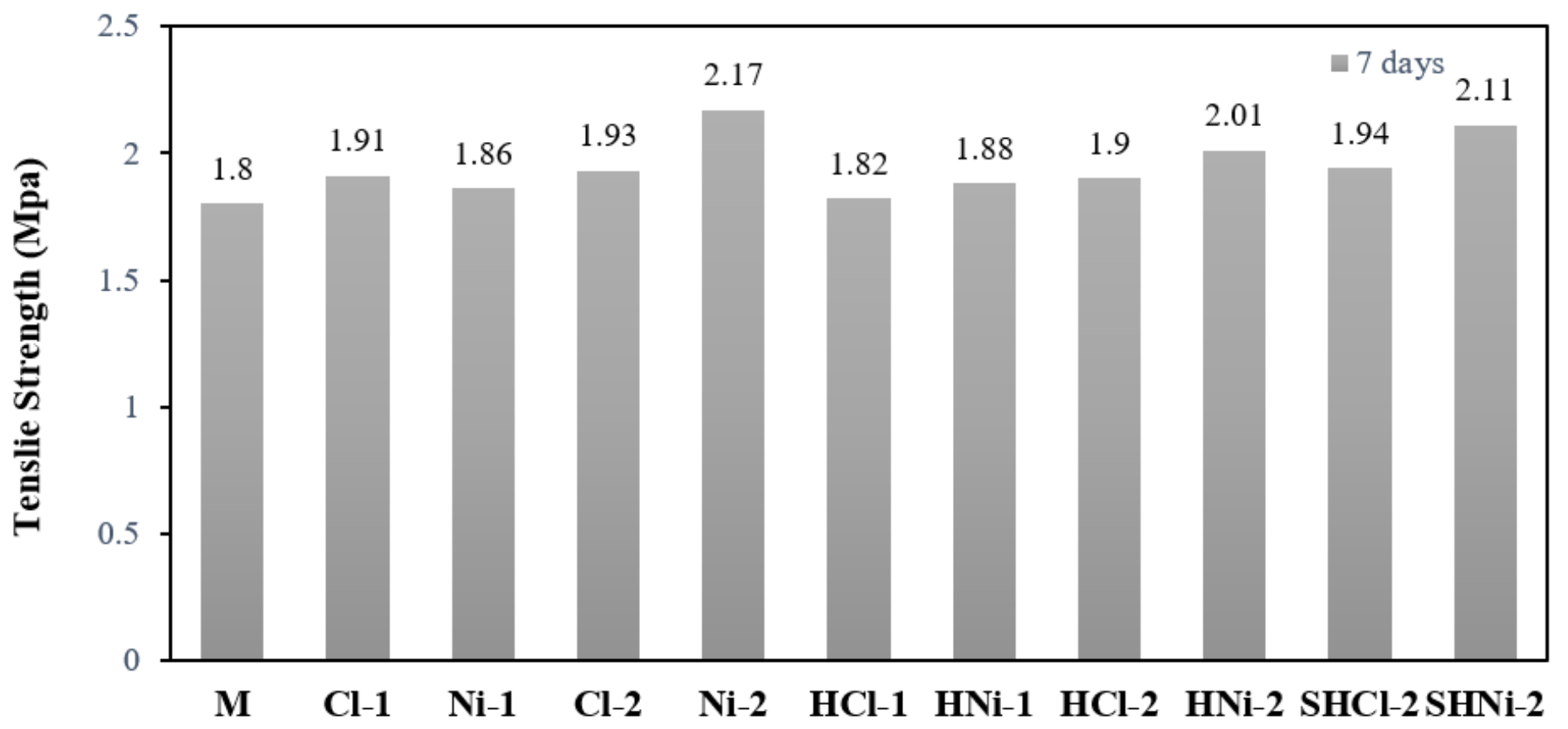

(a)

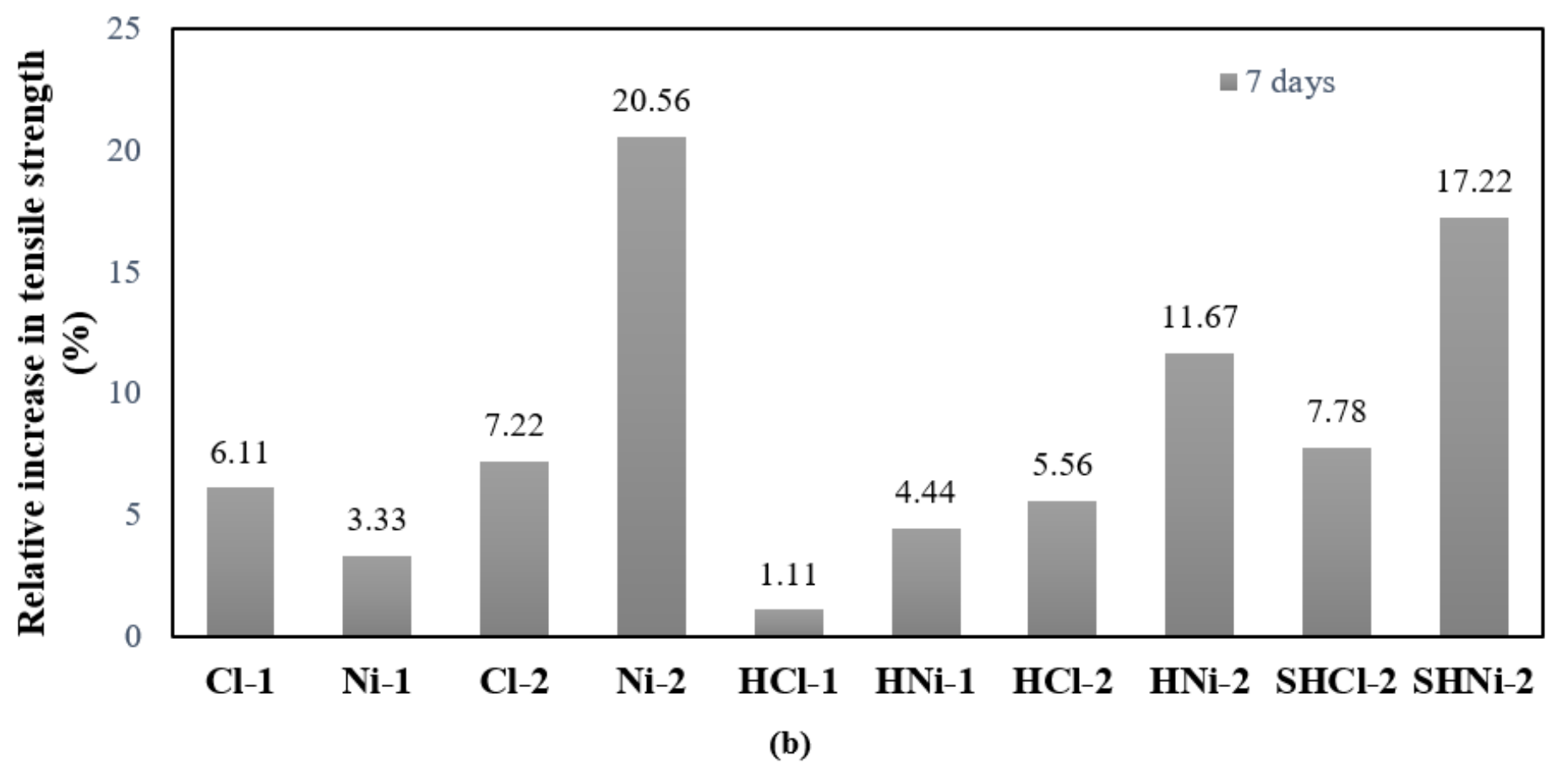

Figure 6

(a) Tensile strength of the mixtures; (b) Relative increase in the tensile strength compared to the control concrete. 
Initial tesnlie strength at 7 days age (Mpa)

The ratio of secondary tensile strength to initial tensile strength

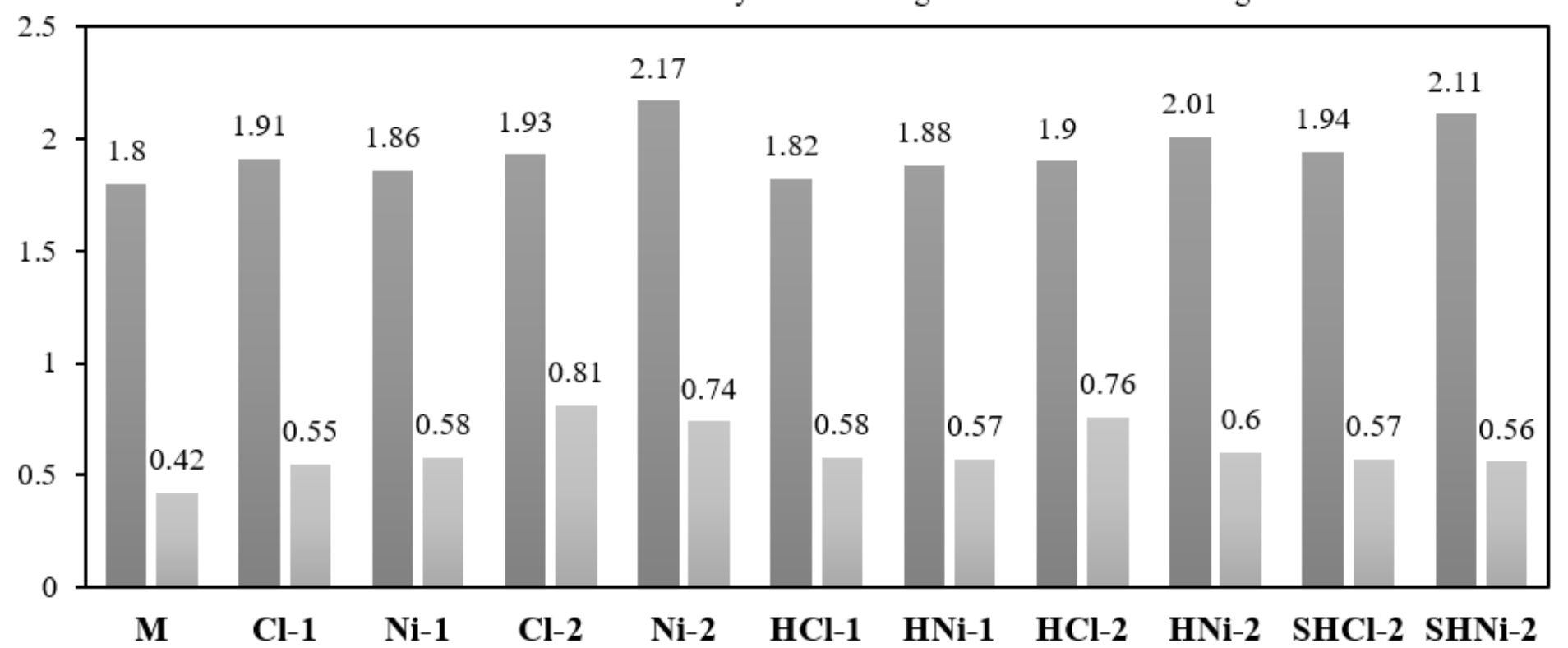

(a)

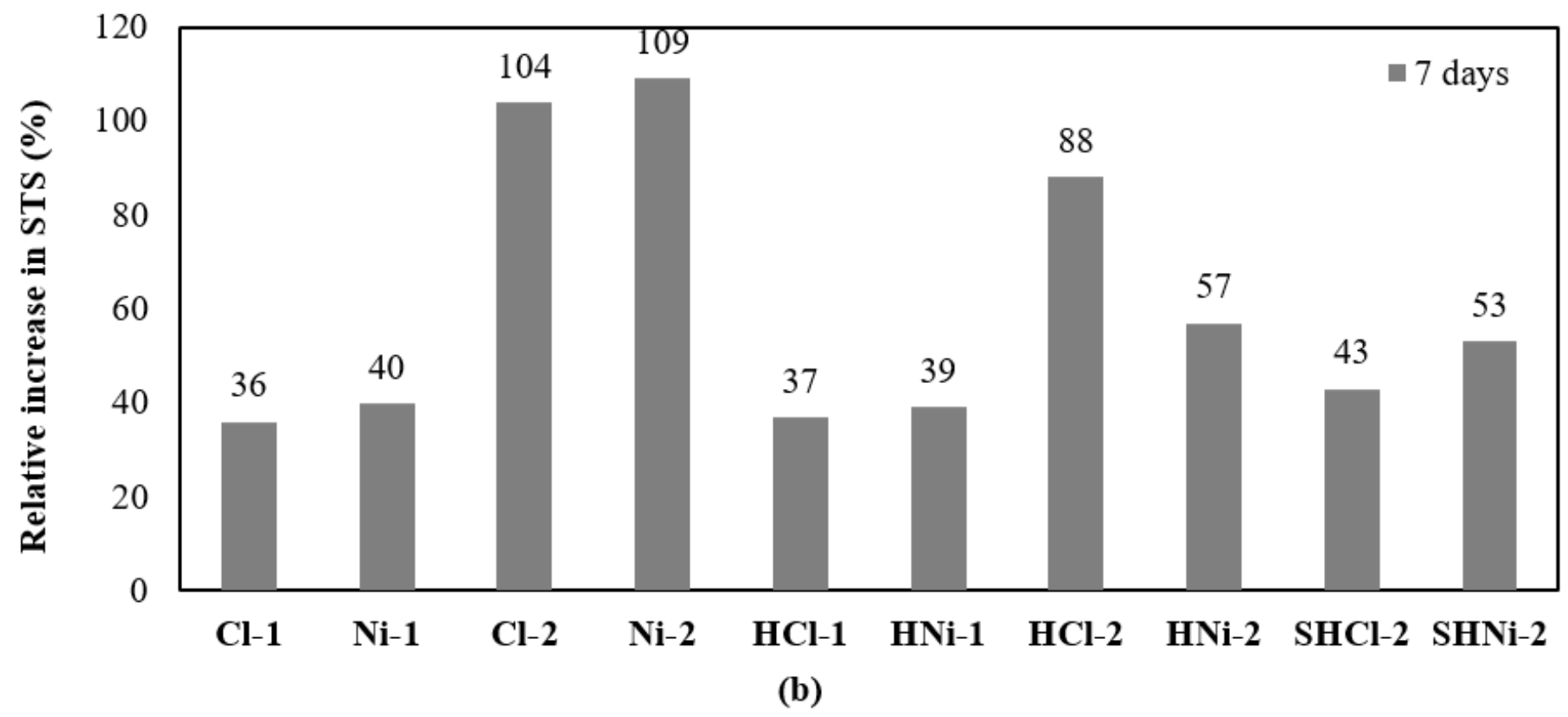

Figure 7

(a) STS and relative STS to initial tensile strength of the mixtures; (b) Relative increase in STS compared to the control concrete. 


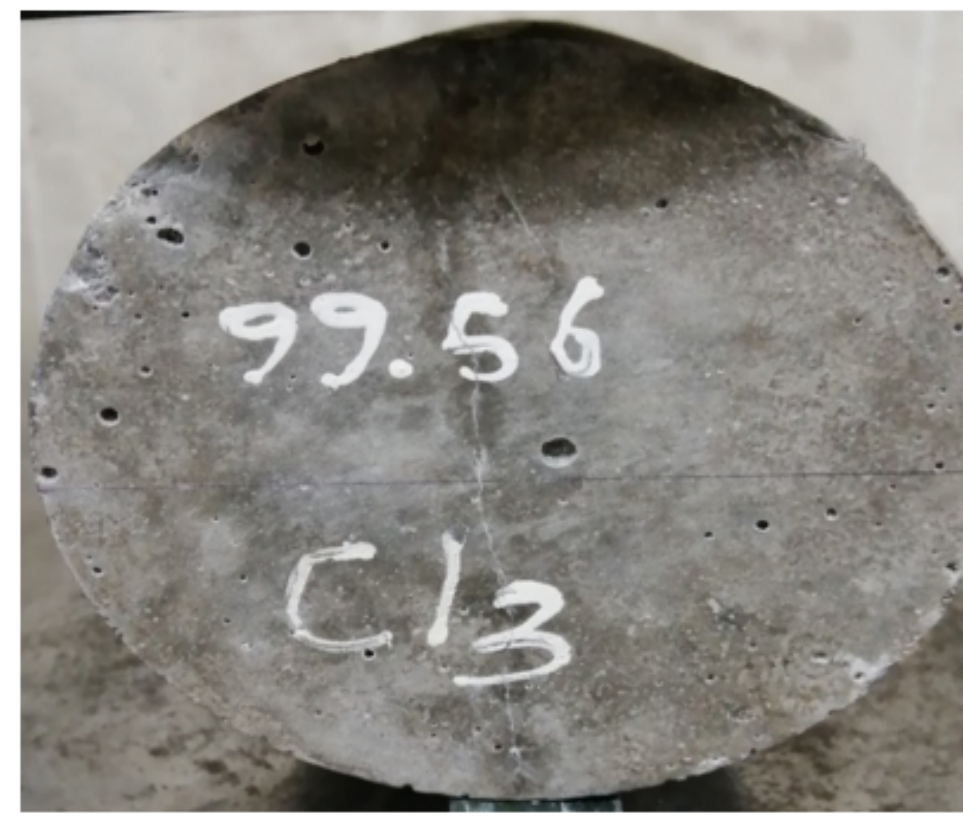

(a)

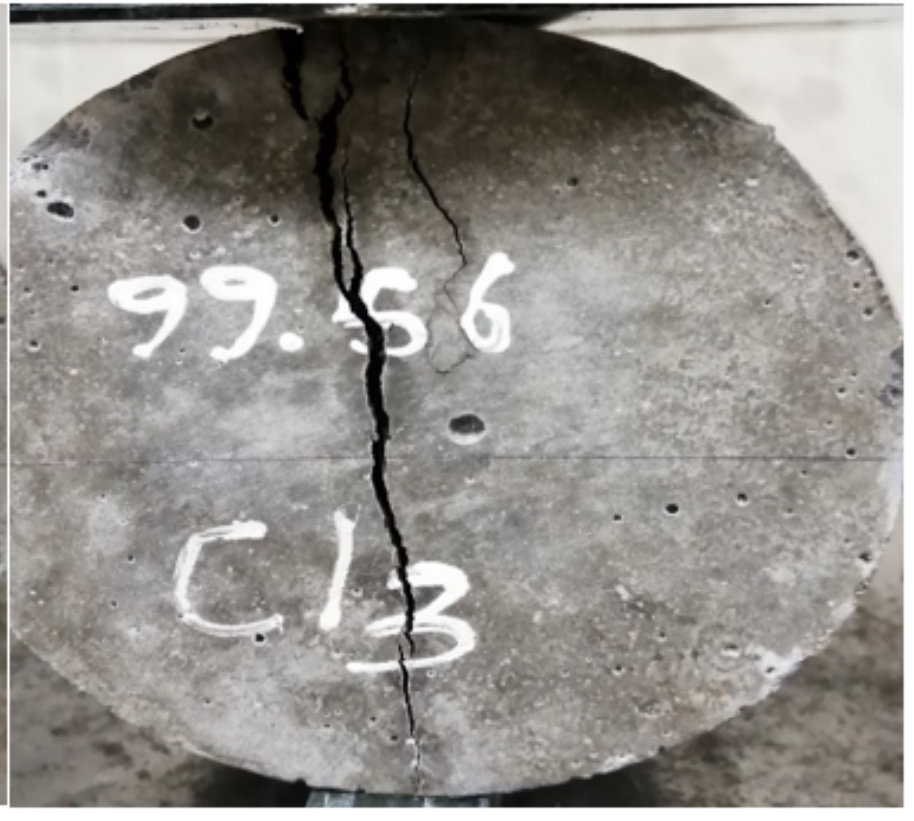

(b)

Figure 8

STS test after 5 weeks of re-curing: (a) before failure; (b) after failure. 


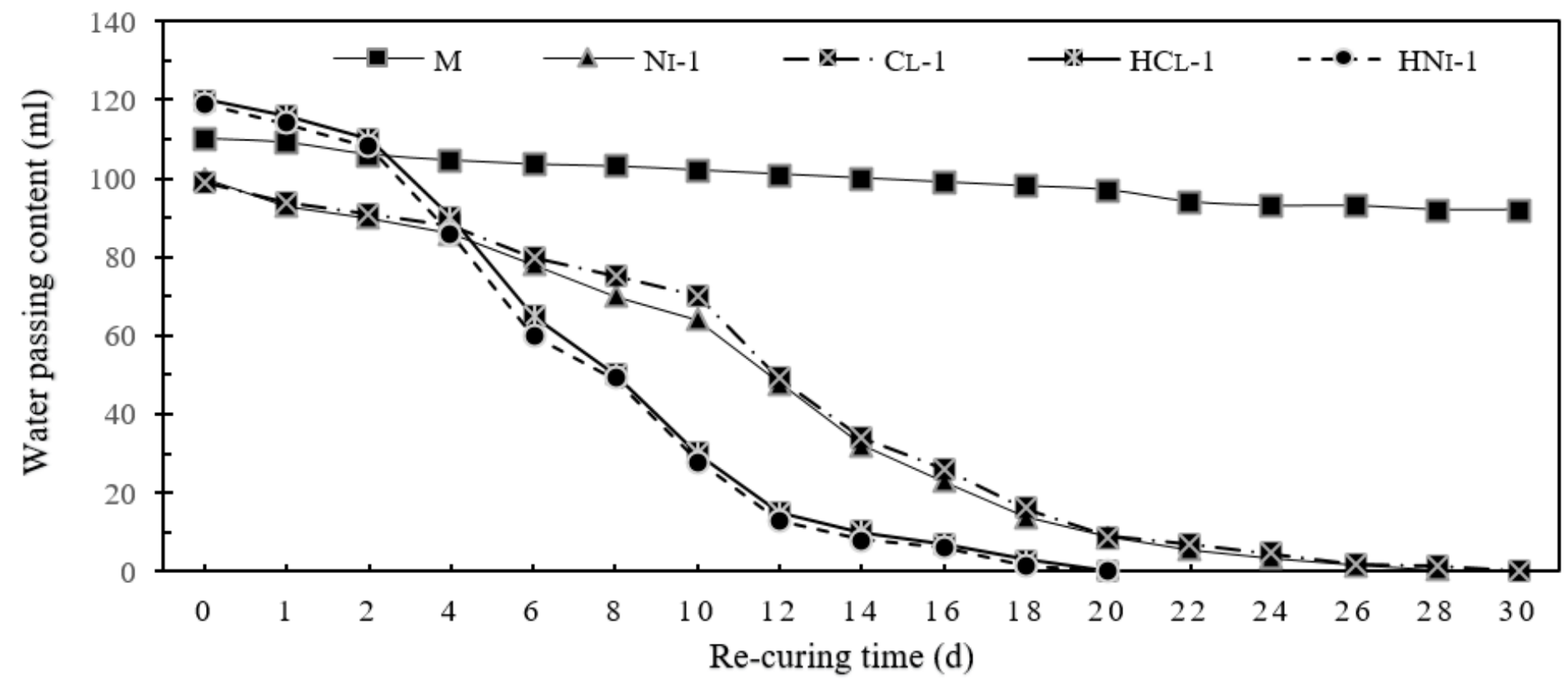

(a)

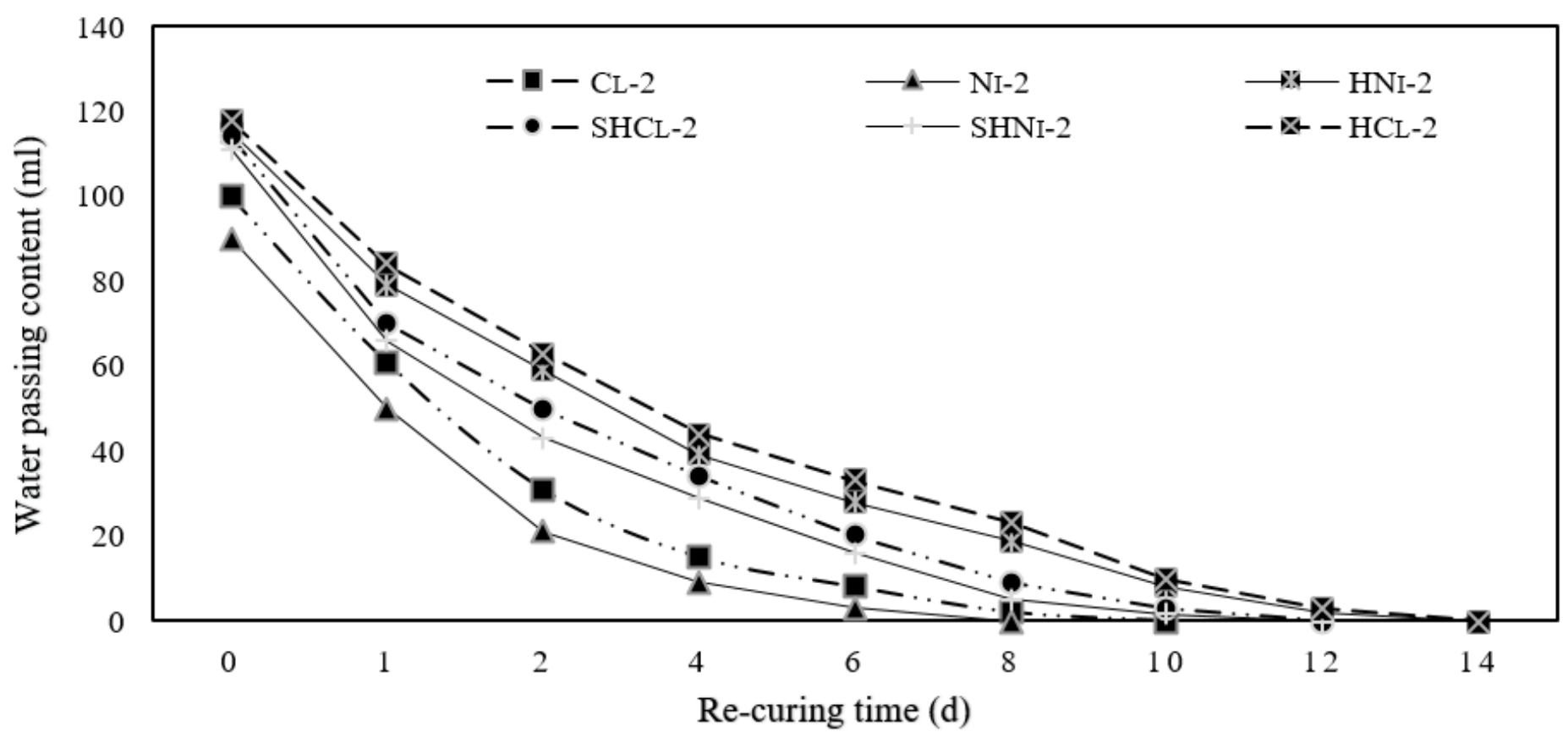

(b)

Figure 9

Water passing content through the crack in the concretes: (a) first group; (b) second group. 


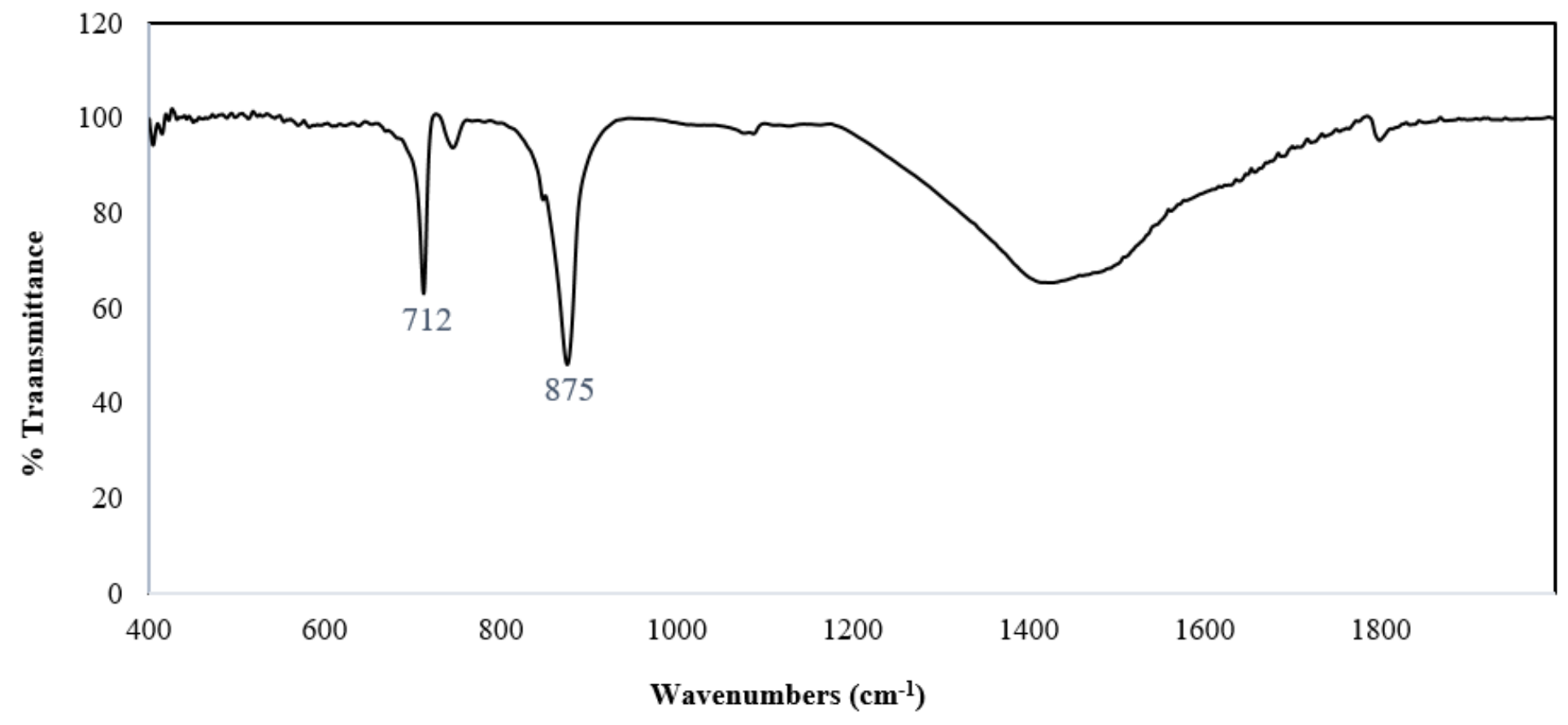

Figure 10

FTIR-Spectra of calcite as self-healing agent.

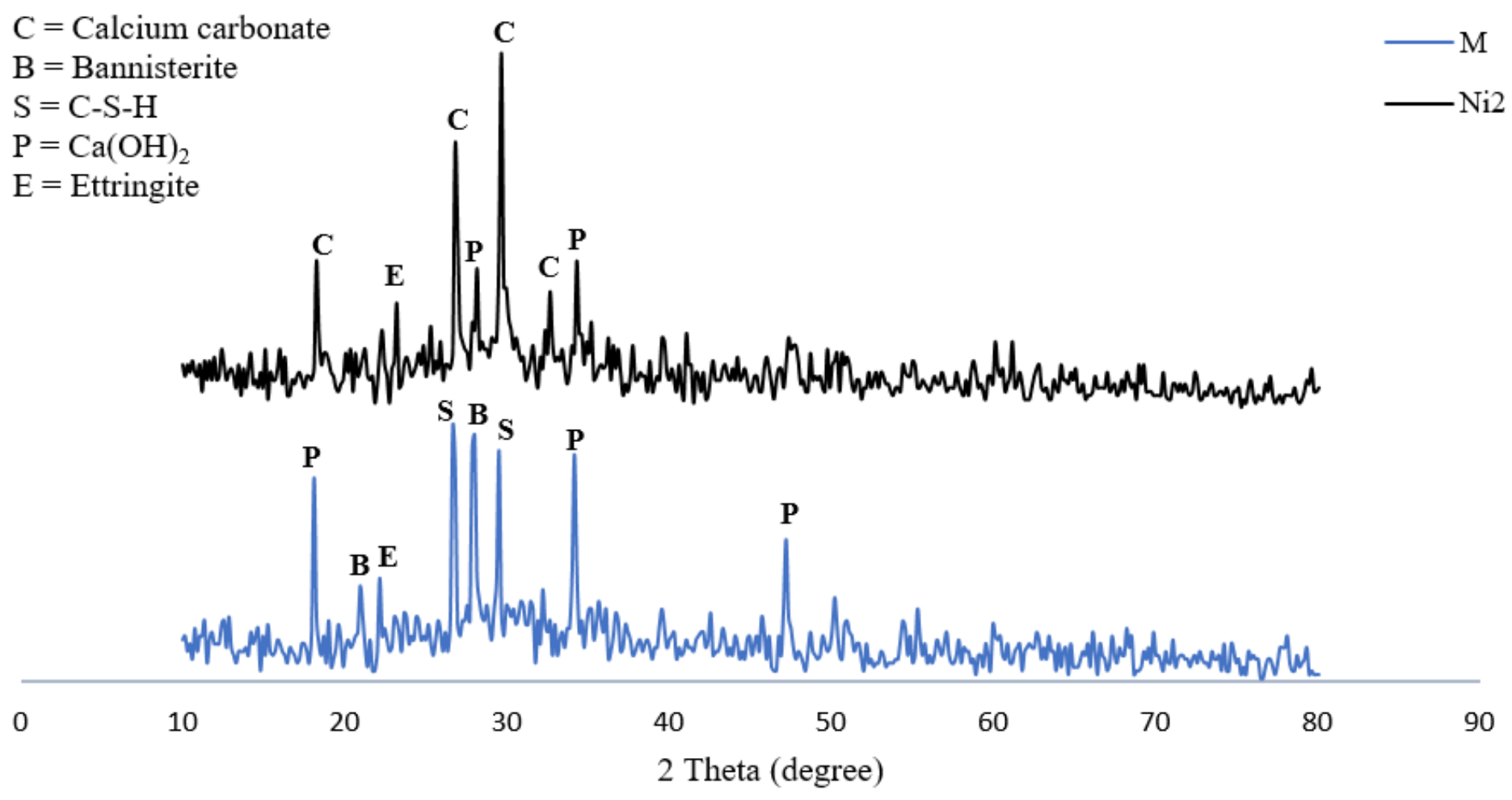

Figure 11

XRD analysis of concrete mix designs, $\mathrm{M}$ and $\mathrm{Ni2}$. 


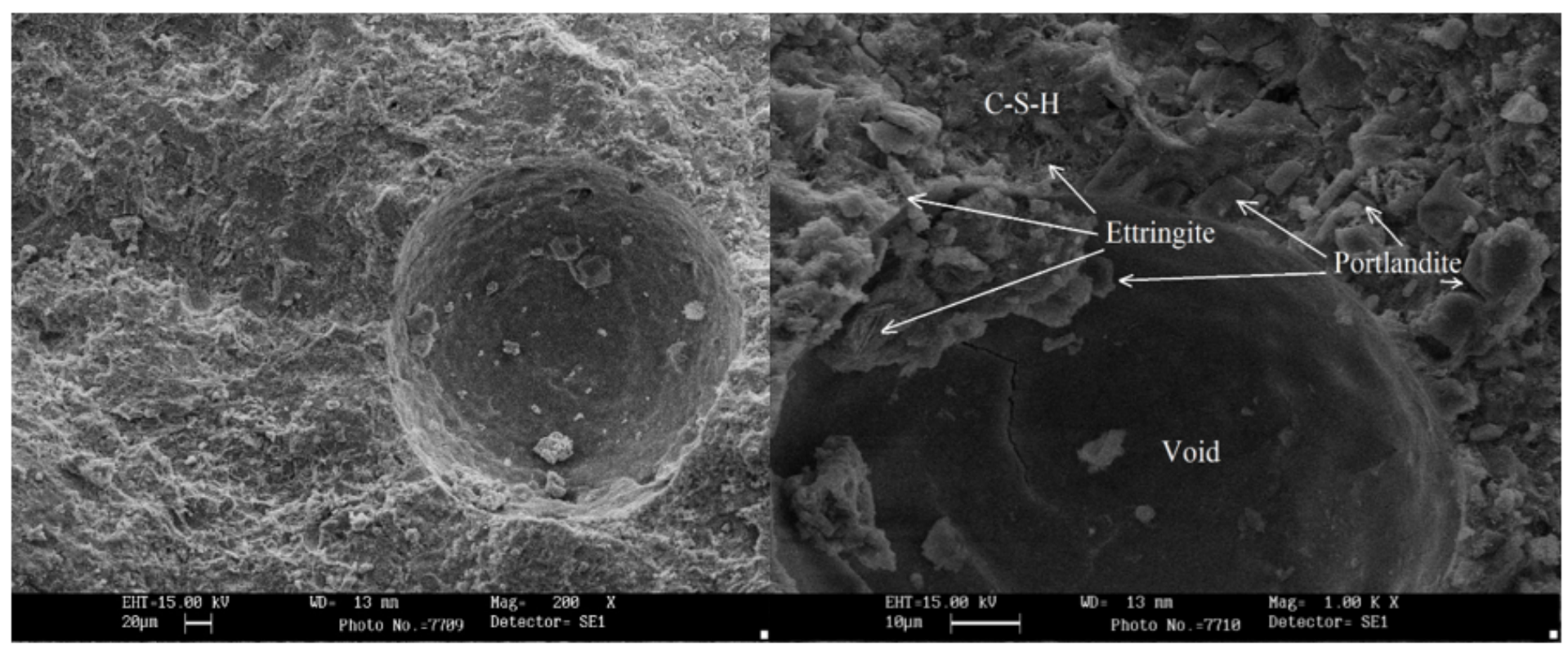

Figure 12

SEM of control concrete (magnification: left-20 $\mu \mathrm{m}$, right-10 $\mu \mathrm{m}$ ).

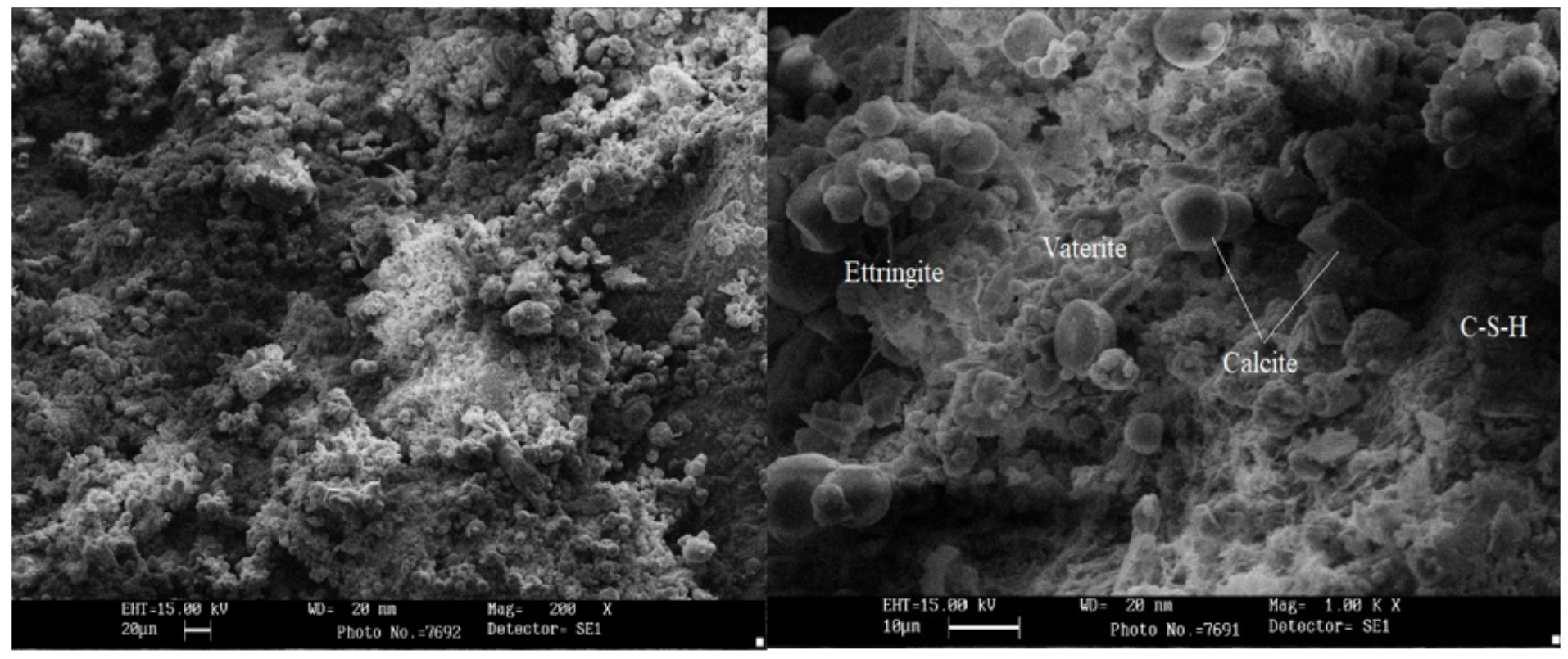

Figure 13

SEM of bacterial concrete containing calcium nitrate-urea (magnification: left- $20 \mu \mathrm{m}$, right-10 $\mu \mathrm{m}$ ). 


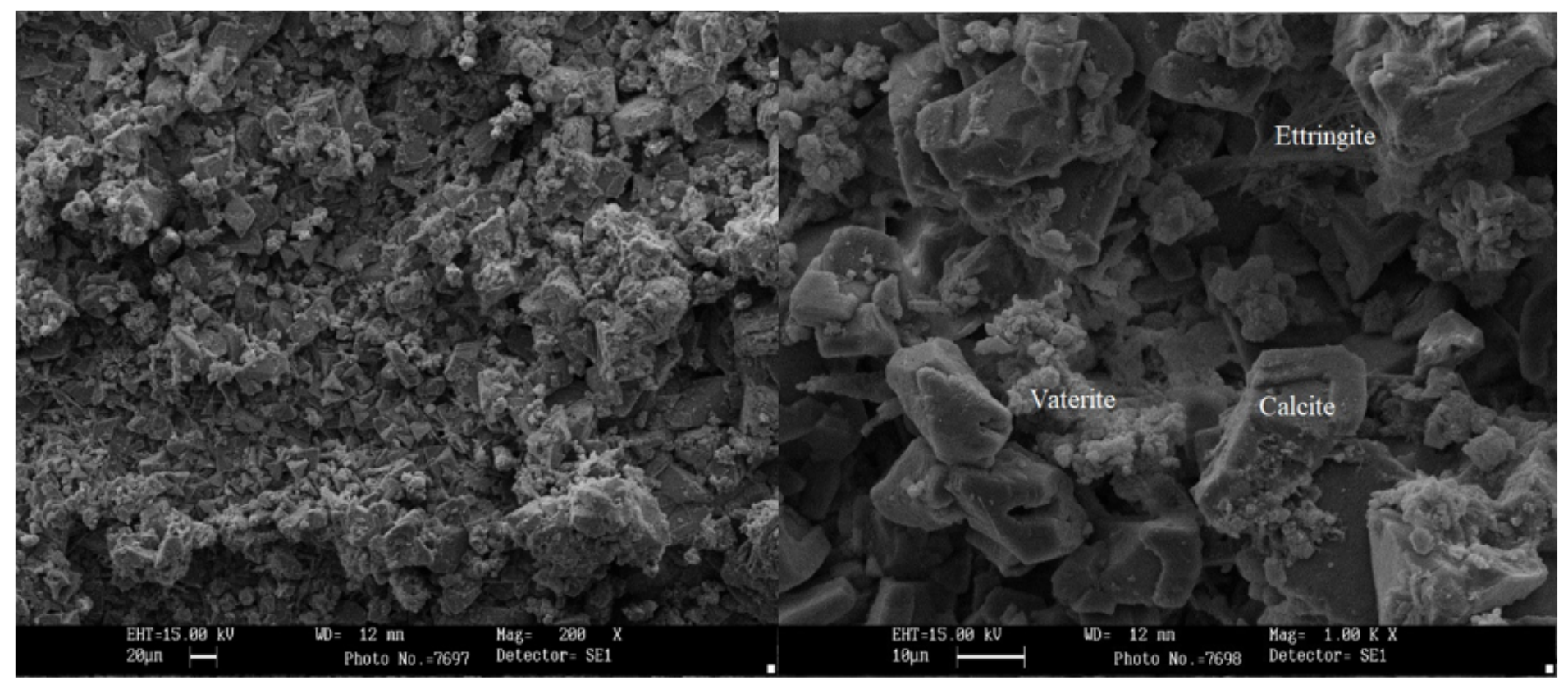

Figure 14

SEM of bacterial concrete containing calcium chloride-urea (magnification: left-20 $\mu \mathrm{m}$, right-10 $\mu \mathrm{m}$ ). 